\title{
Comparative Analysis of the Use of Lipid Modifying Agents in the Republic of Serbia and Nordic Countries in the Period 2015-2017
}

\author{
Nikola B. Martić ${ }^{1}$, Dragan D. Zečević ${ }^{2}$ Milena V. Đurđević ${ }^{1}$, \\ Dragana S. Milijaševićs ${ }^{3}$ Nataša Z. Tomić ${ }^{4}$, Mladena N. Lalić-Popovićs \\ Nemanja B. Todorovićs, Danilo V. Medin ${ }^{6}$, Branimir B. Mićanović ${ }^{1}$, \\ Boris Ž. Milijaševićc
}

\footnotetext{
${ }^{1}$ Department of Pharmacology, Toxicology and Clinical Pharmacology, Faculty of Medicine, University of Novi Sad, Novi Sad, Serbia

${ }^{2}$ International Center for Cardiovascular Diseases - MC Medicor, Izola, Slovenia

${ }^{3}$ Institute of Public Health of Vojvodina, Faculty of Medicine, University of Novi Sad, Novi Sad, Serbia

${ }^{4}$ Emergency Center, Clinical Center of Vojvodina, Novi Sad, Serbia

${ }^{5}$ Department of Pharmacy, Faculty of Medicine, University of Novi Sad, Novi Sad, Serbia

${ }^{6}$ Clinic for Nephrology and Clinical Immunology, Clinical Center of Vojvodina, Novi Sad, Serbia
}

\section{SUMMARY}

Introduction: Cardiovascular diseases are the leading cause of death both in Serbia and in the rest of the world. It has been shown that as many as $80 \%$ of them are preventable. Control of serum lipid levels is one of the most important tasks of cardiovascular diseases prevention.

Aim: The aim of the study was to analyze the use of serum lipid-modifying drugs in Serbia, Norway and Finland in the period 2015-2017.

Methods: Data on drugs use during 2015, 2016 and 2017 were taken from the official websites of national drug regulatory authorities: the Serbian Medicines and Medical Devices Agency, the Norwegian Institute of Public Health and the Finnish Medicines Agency. Use was expressed as DDD/1000 inhabitants/day according to the Anatomical Therapeutic Chemical classification.

Results: The share of drugs used for treatment of cardiovascular diseases in total drugs use was the largest in all three countries during the observed period. The use of lipidmodifying agents was 3-4 times lower in Serbia than in Norway or Finland. Of all lipidmodifying drugs, statins are most commonly prescribed in all three countries. Atorvastatin and rosuvastatin are the most widely used in Serbia, and simvastatin and atorvastatin in Norway and Finland.

Conclusions: Use of lipid-modifying drugs in Serbia is lower than in Norway and Finland, but it is constantly increasing. This use in Serbia still represents the smallest share of all drugs for the treatment of cardiovascular diseases.

Keywords: Cardiovascular Disease Prevention, Hypolipidemic Agents, Statins, Fibrates 


\section{INTRODUCTION}

According to the World Health Organization (WHO), cardiovascular diseases (CVD) are the leading cause of death in the world. In 2016, 17.9 million deaths from CVD were recorded, which represents $31 \%$ of the total mortality in the world [1]. WHO data on the European region show that CVD are the cause of more than a half of deaths [2]. Similar data were also recorded in Serbia, where CVD were the cause of $51.8 \%$ of deaths of all causes in 2018. However, a decrease of $4.5 \%$ in women and $1.7 \%$ in men in the mortality rate due to CVD was noted in Serbia in the period from 2009 to 2018 , although in the same period an increase in the general mortality rate was also observed [3].

Even though CVD are the dominant cause of death in modern times it can be prevented in as many as $80 \%$ of cases. Prevention of CVD means eliminating or reducing risk factors, and it is believed that decreasing of cholesterol level, smoking prevalence and blood pressure level can have the greatest benefits [2]. It is estimated that these three risk factors are responsible for the development of $75 \%$ of all CVD in the world [4].

Hyperlipoproteinemias (HLPs) are metabolic disorders of increased blood lipid levels. The positive effects of lowering blood lipid levels on the occurrence of CVD are well documented. Small changes in lipid levels have a major impact on health. An increase in total cholesterol by $1 \%$ increases the risk of developing ischemic heart disease by $2-3 \%$. It has also been shown that only by reducing low-density lipoproteins (LDL), mortality and morbidity from ischemic heart disease can be reduced by $40 \%$ [4]. This is the precise reason why the treatment of HLPs is the most important tasks of CVD prevention.

There are several classes of drugs used as monotherapy or, if necessary, in combination for the treatment of HLP. The most important groups of hypolipidemic drugs are: 3-Hydroxy-3-methylglutaryl coenzyme A (HMG-CoA) reductase inhibitors (statins), fibrates, anionic-exchange resins, nicotinic acid and cholesterol absorption inhibitors [4]. Numerous randomized studies have shown that the use of statins reduces cardiovascular risk. Statins cause a reduction in serum total cholesterol level and a reduction in the risk of major adverse cardiovascular events in vari- ous patients, for example those with high and low risk, both women and men, younger and older [5-10]. Despite all this knowledge, serum cholesterol-lowering therapy is insufficiently used in the population of patients with high risk of heart attack and CVD. In the PURE study that included 22 countries in 2016, 66\% of people aged 35 years - 70 years with CVD use statins in high-income countries (Sweden and Canada), $27 \%$ in middle-income countries (Poland, Turkey and Brazil) and about $5 \%$ in low-income countries (China and India) $[11,12]$. In the SHARE study in 2013 , only $42 \%$ of people over the age of 50 years with previous CVD taking serum cholesterol-lowering therapy with large variations between different countries $(55 \%$ - 56\% in Belgium, Denmark and Norway; $27 \%$ - 29\% in Estonia and Slovenia) $[11,13]$. The study examining the use of hypolipidemic drugs in Serbia in the period 2004-2008 showed that their use is 6 - 8 times lower than in the Scandinavian countries. An inversely proportional relationship between the use of this group of drugs and CVD mortality was also observed [14]. Insufficient use of hypolipidemic drugs can cause a high incidence of CVD and complications associated with CVD, which includes and a high mortality rate [15 - 17].

\section{AIM}

The aims of this study were:

1. An analysis of the use of drugs in the treatment of HLPs in the Republic of Serbia during 2015, 2016 and 2017.

2. When comparing the use of the same drugs between Republic of Serbia and the Kingdom of Norway and the Republic of Finland, two countries that have well-developed pharmacotherapeutic practices, in the mentioned period.

\section{METHODS}

The analysis was designed as a comparative, pharmaco-economic, retrospective, time series study. Data on drugs use during 2015, 2016 and 2017 were observed. Drugs use data in the Republic of Serbia were taken from the official website of the Medicines and Medical Devices Agency of Serbia (ALIMS) [18-20]. Drugs use data in the Kingdom of Norway 
Table 1. Use of drugs from selected ATC groups expressed in DDD/1000 inh/day and percentages (\%) in Serbia, Norway and Finland during 2015, 2016 and 2017

C - drugs for CVD C10 - lipid modifying agents C10AA - statins were downloaded from the official website of the Norwegian Institute of Public Health $(\mathrm{NIPH})$ [21]. Drugs use data in the Republic of Finland were downloaded from the official website of the Finnish Medicines Agency (FIMEA) [22].

Use of drugs is calculated by the methodology of Defined Daily Doses (DDD) according to the Anatomical Therapeutic Chemical (ATC) classification. DDD is a statistical unit of measure of drug use, the value of which represents the average daily dose of drug use in an adult and does not depend on the price, dosage form and packaging size of the drug. The number of DDD per 1000 inhabitants per day (DDD/1000 inh/day) provides an insight into how many inhabitants (from 1000) used a certain drug and were exposed to its action during the day. Evaluation of drug use over time at the national and international levels has been simplified and improved through the use of DDD [23].

\section{RESULTS}

Use of ATC group C drugs is most dominant in all three countries, during three years of observation. The share of use of lipid-modifying

\begin{tabular}{|c|c|c|c|}
\hline & Serbia & Norway & Finland \\
\hline \multicolumn{4}{|c|}{2015} \\
\hline Total drugs & 1609.01 & 1359.54 & 1779.41 \\
\hline C (\% of total drugs) & 701.41 (43.59) & $417.74(30.73)$ & $557.75(31.34)$ \\
\hline C10 (\% in C) & $37.53(5.35)$ & $128.92(30.86)$ & $105.41(18.90)$ \\
\hline C10AA (\% in C10) & 34.29 (91.37) & $123.20(95.56)$ & $101.35(96.15)$ \\
\hline \multicolumn{4}{|c|}{2016} \\
\hline Total drugs & 1618.17 & 1386.48 & 1776.54 \\
\hline C (\% of total drugs) & $635.12(39.25)$ & $421.08(30.37)$ & $556.16(31.31)$ \\
\hline C10 (\% in C) & $35.27(5.55)$ & $131.84(31.31)$ & $105.77(19.02)$ \\
\hline C10AA (\% in C10) & $31.44(89.14)$ & $124.50(94.43)$ & $101.27(95.74)$ \\
\hline \multicolumn{4}{|c|}{2017} \\
\hline Total drugs & 1519.22 & 1402.48 & 1788.68 \\
\hline C (\% of total drugs) & $624.32(41.09)$ & $424.49(30.27)$ & $568.49(31.78)$ \\
\hline C10 (\% in C) & $38.59(6.18)$ & $135.56(31.93)$ & $112.63(19.81)$ \\
\hline C10AA (\% in C10) & $34.56(89.56)$ & $127.17(93.81)$ & $107.64(95.60)$ \\
\hline
\end{tabular}

agents $(\mathrm{C} 10)$ in ATC group $\mathrm{C}$ has a growth trend during the observed period in all countries. However, the use of ATC group C10 drugs was 3-4 times lower in Serbia than in Norway or Finland. By far the most common C10 representatives were monocomponent statins $(\mathrm{C} 10 \mathrm{AA})$ in all countries during the entire observation period. These data are shown in Table 1.

The share of hypolipidemic drugs in the use of all drugs from group C can be seen in the example from 2017. During 2017, the
Table 2. Distribution of drug use in group $C$ expressed as DDD /1000 inh/day and as a percentages for 2017 between the three observed countries

C - drugs for CVD

C01 - cardiac therapy

C02 - antihypertensives

C03 - diuretics

C04 - peripheral vasodilators

C07 - beta blocking agents

C08 - calcium channel blockers

C09 - agents acting on the renin-angiotensin system

C10 - lipid modifying agents

DDD - DDD/1000 inh/day

\begin{tabular}{|c|c|c|c|c|c|c|}
\hline \multirow{3}{*}{$\begin{array}{c}\text { Country } \\
\text { Country } \\
\text { ATC group }\end{array}$} & \multicolumn{6}{|c|}{2017} \\
\hline & \multicolumn{2}{|c|}{ Serbia } & \multicolumn{2}{|c|}{ Norway } & \multicolumn{2}{|c|}{ Finland } \\
\hline & DDD & $\%$ & DDD & $\%$ & DDD & $\%$ \\
\hline C & 624.32 & 100.00 & 424.49 & 100.00 & 568.49 & 100.00 \\
\hline C01 & 50.41 & 8.07 & 10.03 & 2.36 & 15.19 & 2.67 \\
\hline $\mathrm{CO} 2$ & 2.01 & 0.32 & 4.01 & 0.94 & 2.97 & 0.52 \\
\hline $\mathrm{CO3}$ & 33.03 & 5.29 & 32.01 & 7.54 & 51.68 & 9.09 \\
\hline $\mathrm{CO4}$ & 3.22 & 0.52 & 0.07 & 0.02 & 0.11 & 0.02 \\
\hline $\mathrm{CO}$ & 67.01 & 10.73 & 34.74 & 8.18 & 63.33 & 11.14 \\
\hline C08 & 82.70 & 13.25 & 57.94 & 13.65 & 81.71 & 14.37 \\
\hline C09 & 347.35 & 55.64 & 150.13 & 35.37 & 240.87 & 42.37 \\
\hline C10 & 38.59 & 6.18 & 135.56 & 31.93 & 112.63 & 19.81 \\
\hline
\end{tabular}


total use of hypolipidemic drugs in the territory of the Republic of Serbia amounted to $38.59 \mathrm{DDD} / 1000 \mathrm{inh} /$ day $(6.18 \%)$ and was in fifth place in terms of use of drugs in group C. In the Kingdom of Norway and the Republic of Finland, hypolipidemic drugs are much more represented in the total use of drugs for the treatment of CVD. In the Kingdom of Norway, in 2017, the use of hypolipidemic drugs amounted to $135.56 \mathrm{DDD} / 1000 \mathrm{inh} /$ day $(31.93 \%)$ and was in the second place in terms of use among $\mathrm{C}$ group drugs. In the Republic of Finland, the situation is similar to that in the Kingdom of Norway. Use of hypolipidemic drugs in the Republic of Finland in 2017 was 112.63 DDD/1000 inh/day (19.81\%) and took second place in the use of drugs of group C (Table 2).

In the Republic of Serbia, in the observed period, statins (C10AA) recorded a share of $91.37 \%$ in $2015,89.47 \%$ in 2016 and $90.31 \%$ in 2017 of the total use of hypolipidemic drugs (C10A). During the same period, the share of statins in the Kingdom of Norway and the Republic of Finland accounted for over $95 \%$ of total hypolipidemic drugs use. Statin use in the Kingdom of Norway and the Republic of Finland shows a slight positive trend of several DDD/1000 inh/day, but is present from year to year. In the Republic of Serbia, among the statins, the three most used drugs are atorvastatin, rosuvastatin and simvastatin. Use of simvastatin in the Republic of Serbia during the observed period is quite low and this drug is in third place in terms of statin use. The most used drug from the group of statins in the Republic of Serbia during the observed three years was atorvastatin. Rosuvastatin was the only from statin group that recorded a positive trend during the observed three years and was in second place in terms of statin use. Use of atorvastatin in the Kingdom of Norway shows a positive trend. Use of simvastatin in the Kingdom of Norway during the observed period recorded a negative trend, although this drug is in the second place in terms of statin use during all three observed years. Use of rosuvastatin in the Kingdom of Norway during the observed period recorded a fairly low level (about $4 \%$ of total use of hy-

\begin{tabular}{|c|c|c|c|c|c|c|}
\hline \multirow{3}{*}{$\begin{array}{c}\text { Country } \\
\text { Year } \\
\text { ATC group }\end{array}$} & \multicolumn{6}{|c|}{ Republic of Serbia } \\
\hline & \multicolumn{2}{|c|}{2015} & \multicolumn{2}{|c|}{2016} & \multicolumn{2}{|c|}{2017} \\
\hline & DDD & $\%$ & DDD & $\%$ & DDD & $\%$ \\
\hline $\mathrm{C} 10 \mathrm{~A}$ & 37.53 & 100.00 & 35.14 & 100.00 & 38.27 & 100.00 \\
\hline C10AA & 34.29 & 91.37 & 31.44 & 89.47 & 34.56 & 90.31 \\
\hline C10AA01 & 3.37 & 8.98 & 3.41 & 9.70 & 2.27 & 5.93 \\
\hline C10AA02 & - & - & - & - & - & - \\
\hline C10AA03 & 1.47 & 3.92 & 1.30 & 3.70 & 1.41 & 3.68 \\
\hline C10AA04 & - & - & - & - & - & - \\
\hline C10AA05 & 20.98 & 55.90 & 16.25 & 46.24 & 18.60 & 48.60 \\
\hline C10AA07 & 8.47 & 22.57 & 10.48 & 29.82 & 12.28 & 32.09 \\
\hline $\mathrm{C} 10 \mathrm{AB}$ & 3.24 & 8.63 & 3.70 & 10.53 & 3.70 & 9.67 \\
\hline C10AB02 & - & - & - & - & - & - \\
\hline C10AB04 & - & - & - & - & - & - \\
\hline C10AB05 & 2.60 & 6.93 & 3.15 & 8.96 & 3.14 & 8.20 \\
\hline C10AB08 & 0.64 & 1.71 & 0.55 & 1.57 & 0.56 & 1.46 \\
\hline C10AC & & 0.00 & & 0.00 & & 0.00 \\
\hline C10AC01 & - & - & - & - & - & - \\
\hline C10AC02 & - & - & - & - & - & - \\
\hline C10AC04 & - & - & - & - & - & - \\
\hline C10AX & - & - & - & - & 0.01 & 0.03 \\
\hline C10AX06 & - & - & - & - & - & - \\
\hline C10AX09 & - & - & - & - & 0.01 & 0.03 \\
\hline C10AX14 & - & - & - & - & - & - \\
\hline C10AX15 & - & - & - & - & - & - \\
\hline
\end{tabular}

Table 3. Comparative overview of use of lipid-modifying agents, plain (group C10A) in the Republic of Serbia in the period from 2015 to 2017, expressed by the DDD/1000 inh/ day and percentages (\%)

C10 - lipid modifying agents C10AA - HMG CoA reductase inhibitors

C10AA01 - simvastatin

C10AA02 - lovastatin C10AA03 - pravastatin C10AA04 - fluvastatin C10AA05 - atorvastatin C10AA07 - rosuvastatin C10AB - Fibrates C10AB02 - bezafibrate C10AB04 - gemfibrozil C10AB05 -fenofibrate C10AB08 - ciprofibrate C10AC - Bile acid sequestrants C10AC01- colestyramine C10AC02 - colestipol C10AC04 - colesevelam C10AX - Other lipid modifying agents

C10AX06 - omega-3-triglycerides incl. other esters and acids

C10AX09 - ezetimibe C10AX14 - alirocumab C10AX15 - bempedoic acid DDD - DDD/1000 inh/day 
Table 4. Comparative overview of use of lipid modifying agents, plain (group C10A) in the Kingdom of Norway in the period from 2015 to 2017, expressed by the DDD/1000 inh/ day and percentages (\%)

C10 - lipid modifying agents C10AA - HMG CoA reductase inhibitors

C10AA01 - simvastatin

C10AA02 - lovastatin

C10AA03 - pravastatin

C10AA04 - fluvastatin

C10AA05 - atorvastatin

C10AA07 - rosuvastatin

C10AB - Fibrates

C10AB02 - bezafibrate

C10AB04 - gemfibrozil

C10AB05 -fenofibrate

C10AB08 - ciprofibrate

C10AC - Bile acid sequestrants

C10AC01- colestyramine

C10AC02 - colestipol

C10AC04 - colesevelam

C10AX - Other lipid modifying agents

C10AX06 - omega-3-triglycer-

ides incl. other esters and acids

C10AX09 - ezetimibe

C10AX14 - alirocumab

C10AX15 - bempedoic acid

DDD - DDD/1000 inh/day

\begin{tabular}{|c|c|c|c|c|c|c|}
\hline \multirow{3}{*}{$\begin{array}{c}\text { Country } \\
\text { Year } \\
\text { ATC group }\end{array}$} & \multicolumn{6}{|c|}{ Kingdom of Norway } \\
\hline & \multicolumn{2}{|c|}{2015} & \multicolumn{2}{|c|}{2016} & \multicolumn{2}{|c|}{2017} \\
\hline & DDD & $\%$ & DDD & $\%$ & DDD & $\%$ \\
\hline C10A & 127.85 & 100.00 & 129.70 & 100.00 & 132.91 & 100.00 \\
\hline C10AA & 123.20 & 96.36 & 124.50 & 95.99 & 127.17 & 95.68 \\
\hline C10AA01 & 43.84 & 34.29 & 39.35 & 30.34 & 34.39 & 25.87 \\
\hline C10AA02 & 0.10 & 0.08 & 0.09 & 0.07 & 0.08 & 0.06 \\
\hline C10AA03 & 3.23 & 2.53 & 3.12 & 2.41 & 2.99 & 2.25 \\
\hline C10AA04 & 1.30 & 1.02 & 1.28 & 0.99 & 1.18 & 0.89 \\
\hline C10AA05 & 70.72 & 55.31 & 75.30 & 58.06 & 82.29 & 61.91 \\
\hline C10AA07 & 4.01 & 3.14 & 5.36 & 4.13 & 6.24 & 4.69 \\
\hline C10AB & - & - & - & - & - & - \\
\hline C10AB02 & - & - & - & - & - & - \\
\hline C10AB04 & - & - & - & - & - & - \\
\hline C10AB05 & - & - & - & - & - & - \\
\hline C10AB08 & - & - & - & - & - & - \\
\hline C10AC & 0.15 & 0.12 & 0.15 & 0.12 & 0.16 & 0.12 \\
\hline C10AC01 & 0.08 & 0.06 & 0.08 & 0.06 & 0.09 & 0.07 \\
\hline C10AC02 & 0.02 & 0.02 & 0.01 & 0.01 & 0.01 & 0.01 \\
\hline C10AC04 & 0.06 & 0.05 & 0.05 & 0.04 & 0.06 & 0.05 \\
\hline C10AX & 4.50 & 3.52 & 5.05 & 3.89 & 5.58 & 4.20 \\
\hline C10AX06 & 0.51 & 0.40 & 0.53 & 0.41 & 0.56 & 0.42 \\
\hline C10AX09 & 3.98 & 3.11 & 4.45 & 3.43 & 4.91 & 3.69 \\
\hline C10AX14 & 0.01 & 0.01 & 0.03 & 0.02 & 0.04 & 0.03 \\
\hline C10AX15 & 0.01 & 0.01 & 0.04 & 0.03 & 0.06 & 0.05 \\
\hline
\end{tabular}

polipidemic drugs) and this drug is in third place in terms of statin use. In the Republic of Finland, among the statins, the three most commonly used drugs are simvastatin, atorvastatin and rosuvastatin. The most widely used statin drug in the Republic of Finland during the first two years was simvastatin. Due to the negative trend, simvastatin in the third observed year moved to the second place in terms of statin use, and was replaced by atorvastatin in the first place, which recorded a positive trend in the same period. Another statin that recorded a positive trend during the observed three years is rosuvastatin. It was in third place in terms of statin use.

The share of fibrates in the Republic of Serbia was $8.63 \%$ in $2015,10.53 \%$ in 2016 and $9.67 \%$ in 2017 of all drugs from the C10A group. The most used fibrate in the Republic of Serbia was fenofibrate. In the Kingdom of Norway, the use of fibrates during the observed period was not registered, while in the Republic of Finland it amounted to about $0.50 \%$ of the total use of hypolipidemic drugs.

Ezetimibe is a drug that belongs to the group of other hypolipidemic drugs (group C10AX). It is used as monotherapy or in a fixed combination with simvastatin. Its use in the Republic of Serbia during the observed three years was not registered. In the Kingdom of Norway, ezetimibe use in 2015 was 3.98 $\mathrm{DDD} / 1000 \mathrm{inh} /$ day or $3.11 \%$, in 20164.45 $\mathrm{DDD} / 1000 \mathrm{inh} /$ day or $3.43 \%$ and in 2017 it was $4.91 \mathrm{DDD} / 1000 \mathrm{inh} /$ day or $3.69 \%$ of total hypolipidemic drugs use. A similar situation, when it comes to the use of ezetimibe, is in the Republic of Finland. Ezetimibe use in the Republic of Finland in 2015 was 3.48 DDD/1000 inh/day or $3.30 \%$, in $20163.78 \mathrm{DDD} / 1000$ inh/day or $3.58 \%$ and in 2017 it was 4.21 DDD/1000 inh/day or $3.74 \%$ of total hypolipidemic drugs use.

Use of hypolymeric drugs in the observed countries during 2015-2017 is shown in Tables 3-5.

\section{DISCUSSION}

In all three investigated countries, the use of drugs for the treatment of CVD (group C) 


\begin{tabular}{|c|c|c|c|c|c|c|}
\hline \multirow{3}{*}{$\begin{array}{c}\text { Country } \\
\text { Year } \\
\text { ATC group }\end{array}$} & \multicolumn{6}{|c|}{ Republic of Finland } \\
\hline & \multicolumn{2}{|c|}{2015} & \multicolumn{2}{|c|}{2016} & \multicolumn{2}{|c|}{2017} \\
\hline & DDD & $\%$ & DDD & $\%$ & DDD & $\%$ \\
\hline C10A & 105.38 & 100.00 & 105.68 & 100.00 & 112.51 & 100.00 \\
\hline C10AA & 101.35 & 96.18 & 101.27 & 95.83 & 107.64 & 95.67 \\
\hline C10AA01 & 44.46 & 42.19 & 40.21 & 38.05 & 38.42 & 34.15 \\
\hline C10AA02 & 0.54 & 0.51 & 0.49 & 0.46 & 0.32 & 0.28 \\
\hline C10AA03 & 2.34 & 2.22 & 2.21 & 2.09 & 2.26 & 2.01 \\
\hline C10AA04 & 2.61 & 2.48 & 2.43 & 2.30 & 2.20 & 1.96 \\
\hline C10AA05 & 36.66 & 34.79 & 39.43 & 37.31 & 44.33 & 39.40 \\
\hline C10AA07 & 14.73 & 13.98 & 16.49 & 15.60 & 20.12 & 17.88 \\
\hline C10AB & 0.54 & 0.51 & 0.53 & 0.50 & 0.54 & 0.48 \\
\hline C10AB02 & 0.07 & 0.07 & 0.06 & 0.06 & 0.06 & 0.05 \\
\hline C10AB04 & 0.04 & 0.04 & 0.03 & 0.03 & 0.03 & 0.03 \\
\hline C10AB05 & 0.44 & 0.42 & 0.44 & 0.42 & 0.44 & 0.39 \\
\hline C10AB08 & - & - & - & - & - & - \\
\hline C10AC & 0.01 & 0.01 & 0.10 & 0.09 & 0.12 & 0.11 \\
\hline C10AC01 & - & - & 0.09 & 0.09 & 0.11 & 0.10 \\
\hline C10AC02 & - & - & - & - & - & - \\
\hline C10AC04 & 0.01 & 0.01 & 0.01 & 0.01 & 0.01 & 0.01 \\
\hline C10AX & 3.48 & 3.30 & 3.78 & 3.58 & 4.21 & 3.74 \\
\hline C10AX06 & - & - & - & - & - & - \\
\hline C10AX09 & 3.48 & 3.30 & 3.78 & 3.58 & 4.21 & 3.74 \\
\hline C10AX14 & - & - & - & - & - & - \\
\hline C10AX15 & - & - & - & - & - & \\
\hline
\end{tabular}

Table 5. Comparative overview of use of lipid modifying agents, plain (group C10A) in the Republic of Finland in the period from 2015 to 2017 , expressed by the DDD/1000 inh/ day and percentages (\%)

C10 - lipid modifying agents C10AA - HMG CoA reductase inhibitors

C10AA01 - simvastatin

C10AA02 - lovastatin

C10AA03 - pravastatin

C10AA04 - fluvastatin

C10AA05 - atorvastatin

C10AA07 - rosuvastatin

C10AB - Fibrates

C10AB02 - bezafibrate

C10AB04 - gemfibrozil

C10AB05 -fenofibrate

C10AB08 - ciprofibrate

C10AC - Bile acid sequestrants

C10AC01- colestyramine

C10AC02 - colestipol

C10AC04 - colesevelam

C10AX - Other lipid modifying agents

C10AX06 - omega-3-triglycer-

ides incl. other esters and acids

C10AX09 - ezetimibe

C10AX14 - alirocumab

C10AX15 - bempedoic acid

DDD - DDD/1000 inh/day dominates during the observed period. This use is the highest in absolute and relative terms in the Republic of Serbia.

There is a much higher use of hypolipidemic drugs in the Kingdom of Norway and the Republic of Finland in relation to the use of these drugs in the Republic of Serbia. In all three countries, a discrete increase in the use of $\mathrm{C} 10$ drugs was noted during the observed period. It can be seen it Table 2, that in the Republic of Serbia drugs for the treatment of CVD are used much more than drugs for primary and secondary prevention of these diseases, such as hypolipidemic drugs, similar to the previous study. In addition, a previous study showed that in Serbia, drugs for the prevention of CVD (statins) are used more in secondary than in primary prevention [14]. However, compared to the results from previous study, the use of hypolipidemic drugs in Serbia is higher [15].

Of all hypolipidemic drugs, statins are most commonly prescribed in all three countries. The use of statins has increased in Western societies since the publication of the
Scandinavian Simvastatin Survival Study (4S) in 1994 [25]. After the intensive growth of statin use at the beginning of the 21st century, their use has stabilized in recent years and recorded a slight growth of this group of drugs from year to year. Compared to the previous research, use of statins in Serbia has increased about 24 times from 2004 [15]. In addition to evidence of efficacy and safety, changes in national prescribing requirements are needed to further increase statin use [26]. One of the reasons for significantly lower prescribing of statins in Serbia compared to other countries may be the differences in the legislation on prescribing these drugs [15]. The Republic Health Insurance Fund (RFZO) of the Republic of Serbia has very strict criteria for reimbursement of statin costs. Indications for which statins can be prescribed at the expense of the RFZO in the Republic of Serbia are the prevention of secondary myocardial infarction and stroke and the familial form of HLP. For the first indication, the share of the RFZO is $15-25 \%$ of the price of the medicine, while for the second indication it is $50 \mathrm{RSD}[25,26]$. In 
case of increasing the share of RFZO in the price of statins, as well as in case of expanding indications for prescribing statins at the expense of RFZO (primary prevention of myocardial infarction and stroke in high-risk patients), use of these drugs would increase and consequently RFZO costs for statins. The increase in the use of this group of drugs in Serbia can be attributed, among other things, to the appearance of the National Guide of Good Clinical Practice for the Diagnosis and Treatment of Lipid Disorders in 2012 [4]. This data is especially important, taking into account that in Serbia there has been a decline in mortality rate due to CVD in the previous period [3]. It has also been found that the emergence of generic drugs contributes to an increase in drug use [27]. All these factors probably had an impact on increasing statin use in Serbia, but it is necessary for this trend to continue. In all three countries, prescribing simvastatin decreases in favour of atorvastatin. Possible reasons for this are new studies, such as the CURVES study (Comparative Dose Efficacy Study of Atorvastatin Versus Simvastatin, Pravastatin, Lovastatin, and Fluvastatin in Patients with Hypercholesterolemia) which proved that atorvastatin treatment led to a significantly greater reduction in LDL concentration than equivalent doses of simvastatin [30]. Also, a multicenter study STELAR (Statin Therapies for Elevated Lipid Levels compared Across doses to Rosuvastatin) showed that rosuvastatin at a dose of $10 \mathrm{mg}$ was significantly more effective in lowering atherogenic LDL cholesterol levels than atorvastatin administered at the same dose. This could be the reason for the increase in rosuvastatin prescribing [31]. Although the efficacy of statins is well documented and their positive impact on CVD prevention is known, caution should be exercised when prescribing them. Their pharmacovigilance should be taken into account and prescribed only when they are really necessary [14]. Useful tools have been developed that can be applied when making a statin prescribing decision [32].

Other lipid-modifying drugs, such as fibrates and ezetimibe, have had negligible use both in Serbia and in other two observed countries. These results were expected given that they are second-line drugs for serum lipid reduction, and in line with other published studies $[33,34]$.

\section{CONCLUSION}

During the observed period (2015-2017), the Republic of Serbia was the country with the lowest use of hypolipidemic drugs in relation to the Kingdom of Norway and the Republic of Finland. In the Republic of Serbia, the use of these drugs still represents a low share in the use of all drugs for the treatment of CVD (group C). Although use has increased compared to the previous study, additional pharmacoeconomic steps are needed to match use in Serbia with use in Norway and Finland.

\section{CONFLICT OF INTEREST}

All authors declare that they have no conflict of interest.

\section{REFERENCES}

1. World Health Organization (WHO). Cardiovascular Disease. Key facts. [Internet]. Geneva: World Health Organization; 2017 May. [access 27.09.2020.]. Available at: https://www.who.int/ news-room/fact-sheets/detail/cardiovascular-diseases-(cvds)

2. World Health Organization - Regional office for Europe. Cardiovascular Disease. Data and statistics. [Internet]. [access 27.09.2020.]. Available at: https://www.euro. who.int/en/health-topics/noncommunicable-diseases/cardiovascular-diseases/ data-and-statistics

3. Institute of Public Health of Serbia "Dr Milan Jovanovic Batut". Health Statistical Yearbook of Republic of Serbia 2018. Institute of Public Health: Belgrade, 2009.

4. Milašinović G, editor. National Guide of Good Clinical Practice for the Diagnosis and Treatment of Lipid Disorders. Belgrade: Accreditation Agency for Health Institutions of Serbia; 2012. [in Serbian].

5. Baigent C, Keech A, Kearney PM, Blackwell L, Buck $G$, Pollicino $C$ et al. Efficacy and safety of cholesterol-lowering treatment: prospective meta-analysis of data from 90056 participants in 14 randomized trials of statins. Lancet. 2005;366(9493):1267-78.

6. Cholesterol Treatment Trialists' (CTT) Collaborators. Efficacy of cholesterol-lowering therapy in 18686 people with diabetes in 14 randomized trials of statins: a meta-analysis. Lancet. 2008;371(9607):117-25.

7. Cholesterol Treatment Trialists' (CTT) Collaboration. Efficacy and safety of more intensive lowering of LDL cholesterol: a meta-analysis of data from 170000 participants in 26 randomized trials. Lancet. 2010;376(9753):1670-81. 
8. Cholesterol Treatment Trialists' (CTT) Collaborators. The effects of lowering LDL cholesterol with statin therapy in people at low risk of vascular disease: meta-analysis of individual data from 27 randomized trials. Lancet. 2012;380(9841):581-90.

9. Cholesterol Treatment Trialists' (CTT) Collaboration. Efficacy and safety of LDL-lowering therapy among men and women: meta-analysis of individual data from 174000 participants in 27 randomized trials. Lancet. 2015; 385(9976):1397-405.

10. Cholesterol Treatment Trialists' (CTT) Collaboration. Impact of renal function on the effects of LDL cholesterol lowering with statin-based regimens: a meta-analysis of individual participant data from 28 randomized trials. Lancet Diabetes Endocrinol. 2016;4:829.

11. Collins R, Reith C, Emberson J, Armitage J, Baigent $C$, Blackwell $L$ et al. Interpretation of the evidence for the efficacy and safety of statin therapy. Lancet. 2016;388(10059):2532-61.

12. Yusuf S, Islam S, Chow CK, Rangarajan S, Dagenais G, Diaz R et al. Prospective Urban Rural Epidemiology (PURE) Study Investigators. Use of secondary prevention drugs for cardiovascular disease in the community in high-income, middle-income, and low-income countries (the PURE Study): a prospective epidemiological survey. Lancet. 2011;378:1231-43.

13. Börsch-Supan A, Brandt M, Hunkler C, Kneip T, Korbmacher J, Malter F et al. SHARE Central Coordination Team. Data Resource Profile: the Survey of Health, Ageing and Retirement in Europe (SHARE). Int J Epidemiol. 2013;42(4):992-1001.

14. Deljanin MD, Vuković MH. Pharmacoepidemiological analysis of statins dispensing patterns in pharmacy practice: Profile and side effects. Hospital Pharmacology-International Multidisciplinary Journal. 2016;3(1):354-60.

15. Sabo A, Tomić Z, Stilinović N, Milijašević B, Mikov $M$, Vukmirović $S$, Horvat $O$. Use of serum lipid-reducing drugs in Serbia compared with Scandinavian countries: a population-based study, 2004-2008. Pharmacoepidemiology and drug safety. 2011;20(1):45-9.

16. Raza JA, Babb JD, Movamed A. Optimal management of hyperlipidemia in primary prevention of cardiovascular diseases. Int J Cardiol. 2004;97(3):355-66.

17. La Rosa JC, He J, Vupputuri S. Effects of statins on risk of coronary. a metaanalysis of randomized controlled trials. JAMA. 1999;282(24):2340-6.

18. Rallidis LS, Lekakis J, Kremastinos DT. Current questions regarding the use of statins in patients with coronary heart disease. Int J Cardiol. 2007;122(3):188-94.

19. Radonjić V. Trade and use of medicines for human use in the Republic of Serbia 2015. Belgrade: Medicines and Medical Devices Agency of Serbia;
2016. [In Serbian].

20. Radonjić V. Trade and use of medicines for human use in the Republic of Serbia 2016. Belgrade: Medicines and Medical Devices Agency of Serbia; 2017. [In Serbian].

21. Radonjić V. Trade and use of medicines for human use in the Republic of Serbia 2017. Belgrade: Medicines and Medical Devices Agency of Serbia; 2018. [In Serbian].

22. Norwegian Institute for Public Health. Drug Use in Norway 2013-2017. [internet]. Oslo: Norwegian Institute for Public Health; 2018 [Access 14.09.2019]. Available at: http://www.legemiddelforbruk.no/english/

23. Finnish Medicines Agency Fimea. Finnish Statistics on Medicines 2014-2017. [internet]. Helsinki: Finnish Medicines Agency Fimea; 2018 [Access 14.09.2019]. Available at: http://raportit.nam.fi/ raportit/kulutus/laakekulutus_e.pdf

24. Jakovljević V, Sabo A, Tomić Z, Milijašević B. ATC classification of drugs with defined daily doses for commercial drugs. Orto Medics: Novi Sad, 2007. [In Serbian].

25. Ruokoniemi $\mathrm{P}$, Helin-Salmivaara A, Klaukka T, Neuvonen PJ, Huupponen R. Shift of statin use towards the elderly in 1995- 2005: a nation-wide register study in Finland. British journal of clinical pharmacology. 2008;66(3):405-10.

26. Fuksa L, Vocelka M, Vytrisalova M. The impact of changes in national prescribing conditions for statins on their public expenditure and utilization in the Czech Republic 1997-2013. Health Policy. 2015;119(9):1255-64.

27. Republic Health Insurance Fund. Medicines that are prescribed and dispensed on the prescription form - List A. [Internet]. Belgrade: Republic Health Insurance Fund; 2020. [Access 30.09.2020.]. Available at: https://www.rfzo.rs/download/pravilnici/ lekovi/A\%20Lista_primena\%20od\%2028.08.2020.. pdf

28. Republic Health Insurance Fund. Medicines that are prescribed and dispensed on the prescription form - List A1. [Internet]. Belgrade: Republic Health Insurance Fund; 2020. [Access 30.09.2020.]. Available at: https://www.rfzo.rs/download/pravilnici/ lekovi/A1\%20Lista_primena\%20od\%2028.08.2020.. pdf

29. Mitkova Z, Manova M, Petrova G. Relationship between generic competition and generic utilization of cardiovascular medicines monoproducts in Bulgaria. Pharmacia. 2016;63:3-14.

30. Jones P, Kafonek S, Laurora I, Hunninghake D. Comparative dose efficacy study of atorvastatin versus simvastatin, pravastatin, lovastatin, and fluvastatin in patients with hypercholesterolemia (the CURVES study). Am J Cardiol. 1998;81(5):582-7.

31. Jones PH1, Davidson MH, Stein EA, Bays HE, 
McKenney JM, Miller E, Cain VA, Blasetto JW; STELLAR Study Group. Comparison of the efficacy and safety of rosuvastatin versus atorvastatin, simvastatin, and pravastatin across doses (STELLAR* Trial).Am J Cardiol. 2003;92(2):152-60.

32. Mirković M, Nedeljković M, Ružičić D, Vuković $M$. Development of one-year major adverse cardiac events risk index in patients with acute coronary syndrome and diabetes mellitus who underwent percutaneous coronary intervention. Vojnosanitetski pregled. 2019(00):26-.

33. Wallach-Kildemoes $\mathrm{H}$, Hansen EH. Sociodemographic and diagnostic characteristics of prescribing a second-line lipid-lowering medication: Ezetimibe used as initial medication, switch from statins, or add-on medication. European journal of clinical pharmacology. 2015;71(10):1245-54.

34. Gaviria-Mendoza A, Machado-Duque ME, Machado-Alba JE. Lipid-lowering drug prescriptions in a group of Colombian patients. Biomédica. 2019;39(4):759-68. 


\title{
Uporedna analiza upotrebe lekova u terapiji hiperlipoproteinemija u Republici Srbiji i Nordijskim zemljama u periodu 2015 - 2017. godine
}

\author{
Nikola B. Martić ${ }^{1}$, Dragan D. Zečević ${ }^{2}$, Milena V. Đurđević ${ }^{1}$, Dragana S. Milijašević́ \\ Nataša Z. Tomić ${ }^{4}$, Mladena N. Lalić-Popovićs ${ }^{5}$ Nemanja B. Todorovićs, \\ Danilo V. Medin ${ }^{6}$, Branimir B. Mićanović ${ }^{1}$, Boris Ž. Milijašević ${ }^{1}$

\footnotetext{
${ }^{1}$ Katedra za farmakologiju, toksikologiju i kliničku farmakologiju, Medicinski fakultet, Univerzitet u Novom Sadu, Novi Sad, Srbija

${ }^{2}$ Međunarodni centar za kardiovaskularne bolesti - MC Medicor, Izola, Slovenija

${ }^{3}$ Institut za javno zdravlje Vojvodine, Medicinski fakultet, Univerzitet u Novom Sadu, Novi Sad, Srbija

${ }^{4}$ Urgentni centar, Klinički centar Vojvodine, Novi Sad, Srbija

${ }^{5}$ Katedra za farmaciju, Medicinski fakultet, Univerzitet u Novom Sadu, Novi Sad, Srbija

${ }^{6}$ Klinika za nefrologiju i kliničku imunologiju, Klinički centar Vojvodine, Novi Sad, Srbija
}

\section{KRATAK SADRŽAJ}

Uvod: Kardiovaskularne bolesti su vodeći uzrok smrti u Srbiji i svetu. Pokazano je da su čak $80 \%$ njih preventibilne. Regulisanje nivoa lipida u serumu je jedan od najznačajnijih zadataka prevencije kardiovaskularnih bolesti.

Cilj: Cilj ove studije bio je da se analizira potrošnja lekova za smanjenje nivoa lipida u Srbiji, Norveškoj i Finskoj u periodu 2015-2017.

Metodologija: Podaci o potrošnji lekova tokom 2015, 2016 i 2017 preuzeti su sa zvaničnih veb sajtova nacionalnih regulatornih autoriteta u oblasti lekova: Agencije za lekove i medicinska sredstva Srbije, Norveškog instituta za javno zdravlje i Finske agencije za lekove. Potrošnje su izražene u DDD/1000 stanovnika/dan u skladu sa anatomsko-terapijsko-hemijskom klasifikacijom.

Rezultati: Udeo lekova za kardiovasuklarne bolesti u ukupnoj potrošnji lekova bio je najveći u sve tri zemlje tokom posmatranog perioda. Upotreba lekova za smanjenje lipida bila je 3-4 puta manja u Srbiji nego u Norveškoj ili Finskoj. Od svih hipolipemika, statini su najčešće propisivani u sve tri države. Atorvastatin i rosuvastatin su najšire korišćeni u Srbiji, a simvastatin i atorvastatin u Norveškoj i Finskoj.

Zaključak: Potrošnja hipolipemičnih lekova u Srbiji je manja nego u Norveškoj i Finskoj, ali se neprestano povećava. Potrošnja lekova za smanjenje lipida u Srbiji i dalje zauzima najmanji udeo od svih lekova za kardiovaskularne bolesti.

Ključne reči: prevencija kardiovaskularnih bolesti, hipolipidemici, statini, fibrati 